\title{
PELATIHAN PENERAPAN METODE FIFO DALAM MENILAI PERSEDIAAN KEPADA SISWA-SISWI SMA HARAPAN JAYA
}

\author{
Yanti $^{1}$, Timothy Brian Kurniawan ${ }^{2}$ \\ ${ }^{1}$ Program Studi Fakultas Ekonomi dan Bisnis, Universitas Tarumanagara \\ Surel: yanti@fe.untar.ac.id \\ ${ }^{2}$ Program Studi Fakultas Ekonomi dan Bisnis, Universitas Tarumanagara \\ Surel: timothybk11@gmail.com
}

\begin{abstract}
From the preliminary survey, we found a problem where students at SMA Harapan Jaya had never been given knowledge about how to calculate inventory value using the First In First Out (FIFO) method. For this reason, we from the Faculty of Economics will provide a solution in the form of training on how to calculate inventory value using the FIFO method to students at Harapan Jaya High School. The target that we want to achieve in this training is that after the training is held, the students at SMA Harapan Jaya, who previously did not know how to calculate inventory value using the FIFO method, became familiar with using the FIFO method in assessing inventory. The implementation method that we will use in the training consists of several steps. First, conduct a preliminary survey by conducting interviews with the school. Second, prepare training modules. Third, presenting the module online with Zoom media. Fourth, we will give quizzes before and after training. Fifth, asking students to fill out a questionnaire to assess their satisfaction with the training. The outputs of this PKM activity are: Publications at Senapenmas and Pintar held by Universitas Tarumanagara.
\end{abstract}

Keywords: Inventory, FIFO, SMA Harapan Jaya

\begin{abstract}
ABSTRAK
Dari survey pendahuluan, kami menemukan permasalahan dimana siswa-siswi di SMA Harapan Jaya belum pernah diberikan pengetahuan tentang cara menghitung nilai persediaan dengan metode First In First Out (FIFO). Untuk itu kami akan memberikan solusi dalam bentuk pelatihan cara menghitung nilai persediaan dengan metode FIFO kepada siswa-siswi di sekolah SMA Harapan Jaya. Target yang ingin kami capai dalam pelatihan ini adalah agar setelah pelatihan diadakan, maka siswa-siswi di SMA Harapan Jaya yang sebelumnya belum mengenal tentang cara menghitung nilai persediaan dengan metode FIFO, menjadi paham menggunakan metode FIFO dalam menilai persediaan. Metode pelaksanaan yang akan kami gunakan dalam pelatihan terdiri dari beberapa langkah. Pertama, melakukan survey pendahuluan dengan cara mengadakan wawancara kepada pihak sekolah. Kedua, mempersiapkan modul pelatihan. Ketiga, mempresentasikan modul secara daring dengan media Zoom. Keempat, memberikan contoh kasus sederhana sebelum dan setelah pelatihan kepada siswa-siswi. Kelima, mengevaluasi keberhasilan pelatihan dan meminta para siswa untuk mengisi kuesioner untuk menilai kepuasan mereka atas pelatihan yang telah diberikan. Luaran wajib dari kegiatan PKM ini adalah: Publikasi di Senapenmas dan Luaran Tambahan adalah publikasi di laman Pintar milik Universitas Tarumanagara.
\end{abstract}

Kata kunci: Persediaan, FIFO, SMA Harapan Jaya.

\section{PENDAHULUAN}

SMA Harapan Jaya adalah Sekolah Menengah Atas kategori swasta yang didirikan dengan SK 295/101/1A/1.84 tanggal 27 November 2013, beralamat di Jalan Daan Mogot km.13 Cengkareng Timur, Kecamatan Cengkareng, Kota Jakarta Barat. Saat ini sekolah dipimpin oleh Kepala Sekolah Bapak Junaidi, S.Pd., M.M.

Berdasarkan survey pendahuluan ke SMA Harapan Jaya, kami menemukan masalah bahwa siswa-siswi di SMA Harapan Jaya belum pernah diberikan materi tentang penilaian persediaan barang dagang perusahaan dagang. Untuk itu, pelatihan ini diadakan untuk memberikan solusi tentang cara menggunakan metode FIFO dalam menilai persediaan barang dagang. Contohcontoh kasus yang sederhana akan diberikan sehingga dapat dengan mudah dimengerti oleh siswa-siswi, baik jurusan IPA maupun IPS. 
Topik PKM yang akan kami laksanakan adalah berjudul: Pelatihan Penerapan Metode FIFO dalam Menilai Persediaan Kepada Siswa-Siswi SMA Harapan Jaya. Topik ini menarik dan penting karena beberapa alasan: (a) Persediaan merupakan aset penting perusahaan yang harus dijaga sebaik mungkin, (b) Persediaan akan dilaporkan nilainya dalam laporan keuangan perusahaan, (c) Laporan keuangan merupakan gambaran tentang keadaan suatu perusahaan, (d) Laporan keuangan adalah bentuk tanggung jawab perusahaan pada jajaran direksi, para pemegang saham, para stakeholder, dan pihak manajemen, (e)Laporan keuangan menjadi bukti kredibilitas perusahaan untuk membuat calon investor yakin menanamkan sahamnya, (f) Laporan keuangan menjadi indikator perusahaan dalam melakukan pengambilan keputusan, evaluasi, dan perencanaan, (g) Siswa-siswi SMA Harapan Jaya menjadi tertarik untuk mengenal dan memahami cara-cara menilai persediaan secara ilmiah, (h) Siswa-siswi SMA Harapan Jaya dapat menggunakan pengetahuan yang diperoleh untuk diterapkan ketika menjadi entrepreneur atau ketika ingin melanjutkan pendidikan di perguruan tinggi.

Solusi untuk mengatasi permasalahan yang dialami oleh mitra adalah: kami akan memberikan pelatihan tentang cara penerapan metode FIFO dalam menilai persediaan disertai dengan contohcontoh soal yang sederhana.

Cara suatu perusahaan untuk mengkomunikasikan informasi keuangan yang dimiliki adalah dengan menggunakan laporan keuangan. Informasi keuangan ini dibutuhkan oleh seluruh pengguna (baik internal maupun eksternal perusahaan) untuk mengambil keputusan (Weygandt, et. al., 2018). Beberapa fungsi dari laporan keuangan adalah: (1) Memberikan informasi tentang keadaan finansial perusahaan, (2), Sebagai bentuk tanggung jawab manajemen, sebagai pihak yang dipercaya untuk mengelola perusahaan, kepada para stakeholder atau pihak-pihak yang berkepentingan (3) Bagi calon investor, laporan keuangan akan dianalisis sebelum mereka menanamkan modalnya pada perusahaan, (4) Sebagai dasar atau pedoman bagi perusahaan dalam melakukan pengambilan keputusan, evaluasi, dan perencanaan.

Secara umum ada 5 jenis laporan keuangan penting yang dibuat oleh perusahaan sesuai dengan Standar Akuntansi Keuangan (SAK, 2017) yang berlaku di Indonesia, yaitu: Laporan Laba Rugi, Laporan Perubahan Ekuitas, Laporan Posisi Keuangan, Laporan Arus Kas dan Catatan atas Laporan Keuangan. Berikut penjelasan tentang kelima jenis laporan tersebut. Pertama, Laporan Laba Rugi. Laporan ini menyajikan pendapatan dan beban serta memperlihatkan apakah perusahaan mengalami laba bersih atau rugi bersih dalam satu periode akuntansi (Weygandt, et. al., 2018).

Kedua, Laporan Perubahan Ekuitas. Laporan ini memperlihatkan perubahan ekuitas (modal) selama periode pelaporan, dimana akan disajikan posisi modal awal periode, ditambah dengan laba bersih atau dikurangi rugi bersih yang diperoleh selama periode tersebut, kemudian dikurangi dengan prive. Di akhir laporan akan terlihat modal akhir perusahaan. Berikutnya, modal akhir ini akan dilaporkan dalam Laporan Posisi Keuangan (Yuniarwati, dkk., 2018).

Ketiga, Laporan Posisi Keuangan. Laporan ini dibuat untuk menunjukkan jumlah harta/aset, kewajiban (hutang) dan modal/ekuitas perusahaan pada tanggal tertentu, yaitu tanggal penyusunan laporan keuangan. Keempat, Laporan Arus Kas. Laporan ini berisi tentang informasi kas masuk dan kas keluar yang dihasilkan dari aktivitas operasi, investasi dan pendanaan selama satu periode tertentu (Weygandt, et. al., 2018).

Kelima, Catatan atas Laporan Keuangan. Kieso et.al. (2020) menyatakan bahwa Catatan (notes) merupakan bagian yang tidak terpisahkan dalam melaporkan informasi laporan keuangan. Sebab, Catatan ini berfungsi untuk menjelaskan secara kualitatif terkait dengan item-item khusus dalam laporan keuangan yang informasinya bersifat kuantitatif. Selain itu, Catatan ini juga akan menjelaskan pembatasan-pembatasan yang ditimbulkan oleh suatu perjanjian (kontrak). Oleh sebab itu, Catatan ini sangat bermanfaat bagi pengguna laporan keuangan karena menyajikan informasi-informasi yang sangat diperlukan sebagai dasar dalam pengambilan keputusan. 
Bagi perusahaan dagang atau manufaktur, salah satu jenis harta yang harus dilaporkan dalam laporan keuangan adalah Persediaan. Pengawasan persediaan menentukan kelancaran aktivitas perusahaan serta keefektifan dan efisiensi dari suatu perusahaan (Putra dan Purnawati, 2018). Persediaan memiliki banyak jenis tergantung jenis perusahaannya. Untuk perusahaan dagang, maka persediaan yang mereka miliki disebut persediaan barang dagang. Berbeda dengan perusahaan manufaktur, dimana persediaan yang mereka miliki terdiri dari tiga jenis, yaitu: Persediaan bahan baku, Persediaan barang dalam proses (setengah jadi), dan Persediaan barang jadi.

Persediaan barang dagang merupakan salah satu komponen aset yang paling berharga. Oleh sebab itu, perlu pengendalian yang ketat atas persediaan. Langkah-langkah pengendalian atas persediaan dimulai dengan kegiatan perencanaan, misalnya: menentukan jenis persediaan, menentukan bagaimana cara menyetoknya, menentukan pemasok, menentukan bagian-bagian mana saja yang bertanggungjawab atas pengadaan, penyimpanan, dan penggunaan persediaan, dan lain sebagainya. Berikutnya adalah mencatat dan menilai persediaan dengan metode yang tepat, misalnya apakah menggunakan penilaian dengan metode FIFO, Average, perpetual, atau periodik, dan sebagainya. Terakhir, adalah langkah pengendalian, yaitu membandingkan apakah persediaan telah dikelola sesuai dengan rencana.

Secara periodik pada saat penyusunan laporan keuangan, maka akuntan perusahaan harus menentukan nilai persediaan akhir yang harus dilaporkan. Jumlah fisik persediaan barang akan dikalikan dengan biaya per unitnya untuk mendapatkan nilai dari persediaan akhir. Akuntansi dalam perusahaan dagang membedakan dua sistem pencatatan persediaan barang dagang berikut ini, yaitu: Sistem pencatatan perpetual dan Sistem pencatatan periodik. Berikut penjelasannya.

Sistem pencatatan perpetual. Beberapa ciri-ciri sistem perpetual adalah sebagai berikut. Pertama, Pembelian barang dagang, retur pembelian, potongan pembelian, ongkos angkut, dan diskon pembelian barang dagang, akan dicatat ke dalam akun tunggal yaitu Persediaan. Kedua, setiap terjadi penjualan, maka akuntan akan mendebet akun harga pokok penjualan dan mengkredit persediaan. Salah satu kelebihan sistem pencatatan persediaan metode perpetual yakni perusahaan tidak perlu melakukan perhitungan fisik (stock opname) pada stok tersisa. Alasannya, perusahaan dapat mengetahui stok yang sebenarnya di lapangan dengan mudah berkat adanya pencatatan yang dilakukan setiap waktu.

Sistem pencatatan periodik. Berbeda dengan sistem pencatatan perpetual, sistem ini tidak mendebet ataupun mengkredit akun Persediaan saat terjadi transaksi yang berkaitan dengan bertambah atau berkurngnya persediaan. Demikian juga ketika terjadi penjualan barang dagang, akun harga pokok penjualan tidak dicatat, namun akan dihitung pada akhir periode akuntansi. Beberapa ciri-ciri sistem periodik adalah sebagai berikut. Pertama, ketika terjadi pembelian barang dagang, akan didebet ke akun Pembelian. Transaksi retur pembelian akan dikredit ke akun Retur Pembelian. Transaksi diskon pembelian, akan dikredit ke akun Diskon Pembelian, sedangkan saat pembayaran ongkos angkut pembelian, akan dicatat ke sisi debet akun Ongkos Angkut Masuk. Kedua, saat terjadi penjualan barang dagangan, maka akun kas atau piutang akan didebet dan akun penjualan dicatat di sisi kredit. Perusahaan yang menjual barang dagangan dalam kuantitas banyak, frekuensi yang tinggi, nilainya relatif kecil dan harga jual-beli yang relatif stabil, adalah yang memakai sistem pencatatan persediaan metode periodik. Kelebihan metode periodik yakni perusahaan selalu dapat mengetahui besarnya persediaan dalam gudang secara akurat karena sering melakukan stock opname. Namun, sistem pencatatan ini mempunyai kelemahan, yaitu sulit mengetahui jumlah persediaan awal dan akhir pada satu periode.

Metode pencatatan dan metode penilaian persediaan adalah dua hal yang berbeda. Untuk menilai persediaan, akuntansi memberikan beberapa metode, salah satunya adalah berdasarkan cost flow assumption (arus keluar masuknya harga beli). Terdapat dua metode berdasarkan cost flow assumption ini, yaitu: metode FIFO (First In First Out) dan metode Average (Weygandt, et.al., 
2018). Metode penilaian persediaan akan disesuaikan dengan metode pencatatan persediaan dalam sebuah perusahaan (perpetual ataukah periodik).

Metode FIFO (First in First Out) mengasumsikan bahwa "earliest goods purchased are the first to be sold". Sekalipun metode ini paralel dengan keluar masuknya barang secara fisik, namun metode ini tidak mengharuskan perusahaan untuk menjual barang dagang secara berurutan sesuai dengan arus masuknya barang dagang. Namun, metode FIFO adalah tentang cara menentukan harga pokok penjualan berdasarkan harga pembelian yang lebih dulu dibeli. Pada akhir periode, harga pokok persediaan akhir akan dihitung berdasarkan pada harga pembelian barang yang paling akhir. Ilustrasinya adalah sebagai berikut. Perusahaan ABCD mempunyai saldo awal persediaan tanggal 1 Juni sebanyak 200 unit @ \$ 5. Pada 12 Juni, perusahaan membeli 300 unit @ \$6. Pada 23 Juni, perusahaan membeli 500 unit @ \$ 7. Pada 15 Juni, perusahaan menjual 400 unit dan pada 27 Juni, perusahaan membeli 440 unit. Cara menilai persediaan akhir dengan menggunakan metode FIFO untuk metode pencatatan persediaan secara Perpetual dapat dilihat pada Tabel 1 berikut ini.

\section{Tabel 1}

Menilai Persediaan Akhir Dengan Menggunakan Metode FIFO Untuk Metode Pencatatan Persediaan Secara Perpetual

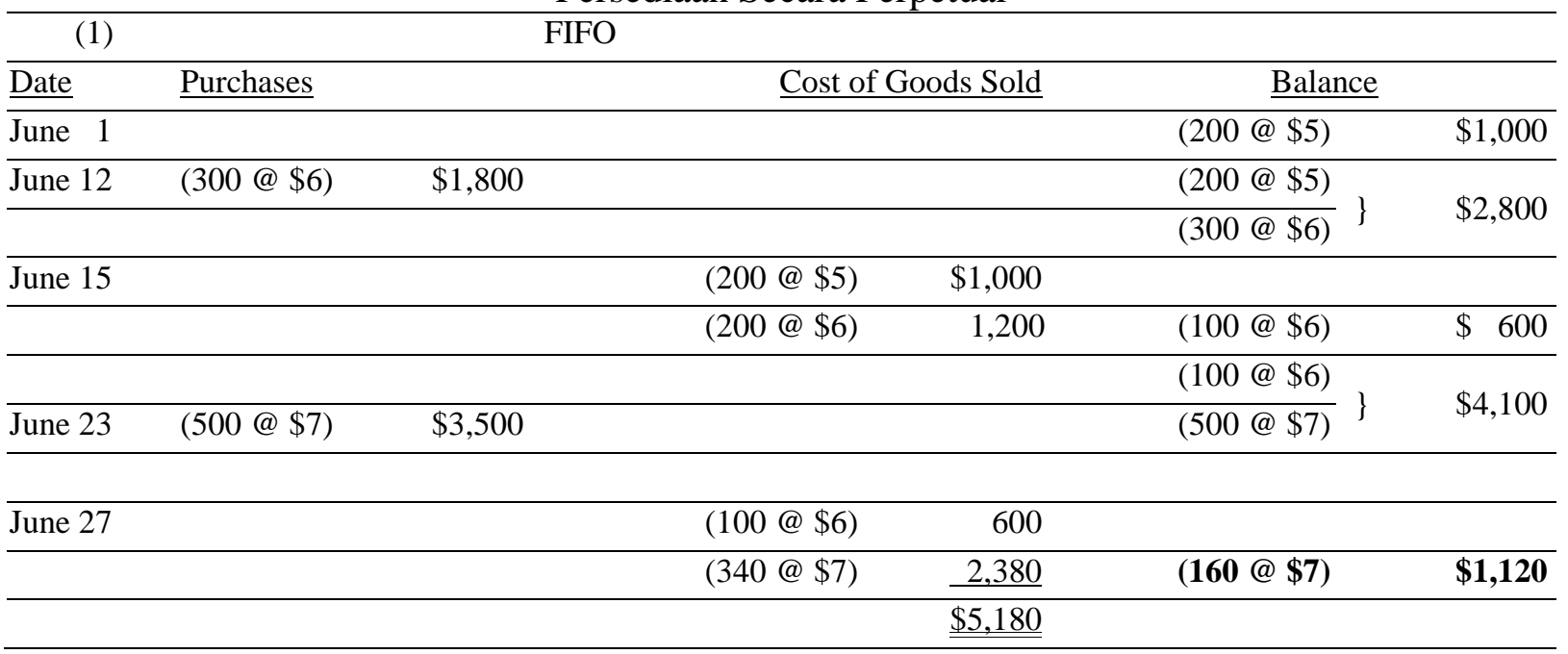

Dari tabel perhitungan di atas, maka persediaan akhir persediaan barang dagang perusahaan adalah berjumlah $\$ 1,120$.

Sementara itu, menilai persediaan akhir dengan menggunakan metode FIFO untuk metode pencatatan persediaan secara Periodik, tidak memerlukan tabel perhitungan seperti halnya metode pencatatan persediaan Perpetual di atas. Namun, nilai persediaan akhir akan langsung dikalikan dengan harga beli di tanggal yang terakhir perusahaan beli periode tersebut. Mengapa demikian? Karena sesuai dengan prinsip FIFO, maka barang dagang yang dijual pertama, harga (cost)nya akan dikalikan dengan harga beli yang pertama juga (first in first out) dan seterusnya. Sehingga pada akhir periode ketika terdapat barang-barang yang belum laku (sisa), harga yang akan dikalikan adalah dengan harga terakhir mereka beli.

Berdasarkan ilustrasi tersebut PT. ABCD sebelumnya, maka jumlah persediaan akhir PT. ABCD adalah: Unit awal + unit beli - unit jual = Unit akhir. Maka 200 unit $+(300+500)$ unit $(400+440)$ unit, maka jawabannya adalah 160 unit. Sedangkan nilai unit persediaan akhir menurut metode FIFO periodik adalah $=160 \times$ x $\$$ (harga beli di tanggal terakhir yaitu tanggal 23 Juni) $=\$ 1,120$.

\section{METODE PELAKSANAAN PKM}

Dalam kegiatan PKM ini, tahapan atau langkah-langkah yang akan kami gunakan adalah: 
1. Membuat Modul yang berisi teori atau konsep yang terkait dengan analisis laporan keuangan.

2. Modul dijelaskan secara daring dengan aplikasi Zoom dan Microsoft Power Point.

3. Memberikan sebuah soal sederhana untuk dikerjakan oleh siswa-siswi, sebelum dan setelah pelatihan diberikan, sehingga dapat mengevaluasi efektifitas pelatihan.

4. Meminta siswa-siswi mengisi kuesioner tentang kegiatan pelatihan kami, menggunakan google form, agar dapat menjadi masukan bagi kami dalam kegiatan PKM selanjutnya.

Dalam kegiatan ini, Mitra PKM yaitu SMA Harapan Jaya akan berpartisipasi dalam beberapa hal, yaitu: (a) Menyiapkan Surat Pernyataan Mitra, (b) Menginformasikan dan mengkomunikasikan pelatihan ini kepada para siswa yang akan mengikutinya, dan (c) Menyiapkan siswa-siswi yang akan ikut pelatihan secara daring.

\section{HASIL DAN PEMBAHASAN}

Kegiatan PKM akan dilaksanakan pertengahan bulan Oktober 2021 sesuai kesepakatan dengan pihak mitra (pihak sekolah). Modul pelatihan dan Microsoft Power Point sudah selesai disusun oleh Tim Pelatih, dan akan dipresentasikan dengan menggunakan media zoom dalam tiga sesi. Sesi pertama, siswa-siswi akan diberikan sebuah soal sederhana untuk dikerjakan sesuai dengan topik pelatihan, dengan tujuan untuk mengetahui sejauh mana pengetahuan mereka atas topik yang akan diberikan. Sesi kedua, dosen pelatih akan memaparkan materi pelatihan. Dan sesi yang ketiga, siswa-siswi mengerjakan kembali soal yang telah diberikan, dengan tujuan untuk mengevaluasi hasil pelatihan.

\section{KESIMPULAN}

Setelah melaksanakan kegiatan PKM ini, kami mengharapkan siswa-siswi SMA Harapan Jaya yang semula tidak mempunyai ilmu pengetahuan tentang cara menilai persediaan dengan metode FIFO, maka setelah diadakannya PKM ini, mereka dapat mengerti dan memahami tentang cara menilai persediaan dengan metode FIFO. Dengan ilmu ini, mereka dapat mempraktikkannya di masyarakat, ketika bekerja, berwirausaha, ataupun ketika melanjutkan pendidikan ke jenjang yang lebih tinggi.

\section{Ucapan Terima Kasih}

Kami mengucapkan banyak terima kasih kepada Rektor Universitas Tarumanagara, Ketua Lembaga Penelitian dan Pengabdian pada Masyarakat (LPPM) Universitas Tarumanagara, Dekan dan jajaran pimpinan Fakultas Ekonomi Universitas Tarumanagara, Mitra PKM SMA Harapan Jaya, serta semua pihak yang tidak dapat kami sebutkan satu per satu.

\section{REFERENSI}

Ikatan Akuntan Indonesia. (2017). Standar Akuntansi Keuangan Efektif Per 1 Januari 2017. Jakarta. Ikatan Akuntan Indonesia.

Kieso, Donald E., Jerry J. Weygandt., Terry D. Warfield. (2020). Intermediate Accounting. IFRS Edition. 4nd Edition. USA. John Wiley \& Sons, Inc

Putra, Dewa Gede Eka Narendra Putra dan Ni Ketut Purnawati. (2018). Kinerja Manajemen Persediaan Barang Dagangan Pt. Artha Dinamis Sentosa Bali. E-Jurnal Manajemen Unud, Vol. 7, (10), 5599-5627. https://doi.org/10.24843/EJMUNUD.2018.v7.i10.p14.

Weygandt, Jerry J., Paul D. Kimmel, dan Donald E. Kieso. (2018). Financial Accounting. IFRS Edition. 4nd Edition. USA. John Wiley \& Sons, Inc

Yuniarwati, Linda Santioso, Agustin Ekadjaja, Nurainun Bangun. (2018). Pengantar Akuntansi 2 Belajar Mudah Akuntansi. Jakarta. Mitra Wacana Media. 
Seminar Nasional Hasil Penelitian dan Pengabdian Kepada Masyarakat 2021

Pengembangan Ekonomi Bangsa Melalui Inovasi Digital Hasil Penelitian dan

Pengabdian Kepada Masyarakat

Jakarta, 21 Oktober 2021

(halaman kosong) 